\title{
Tutorial Submit Articles on the Open Journal System (OJS)
}

\author{
Chandra Prasadhita ${ }^{1^{*}}$, Galih Fajar Muttaqin², Dabella Yunia ${ }^{3}$ \\ ${ }^{*}, 2,3$ University of Sultan Ageng Tirtayasa University, Indonesia \\ chandraprasadhita@untirta.ac.id ${ }^{11}$
}

\begin{abstract}
Submit artikel pada Online Journal System (OJS) selama ini dipandang sebagai hal yang sulit bagi masyarakat. Program pengabdian kepada masyakat yang diusulkan ini merupakan program pengabdian kepada masyakat yang bertujuan untuk memberikan solusi kemudahan bagi masyarakat untuk mempublikasikan hasil penelitian. Masyakat dapat memanfaatkan teknologi yang untuk mempublikasikan karya melalui Open Journal System (OJS). Berdasarkan latar belakang tim pengusul dan pengalaman tim pengusul, maka dengan ini, tim mengajukan program pengabdian kepada masyarakat dengan tema "Tutorial Submit Artikel pada Online Journal System (OJS)“. Pelatihan akan dilakukan pemaparan materi dan praktik. Hasil dari kegiatan yang dilakukan ini diharapkan dapat memberikan manfaat kepada akademisi dan peneliti yang lain untuk mempublikasikan karya..
\end{abstract}

Katakunci: Article, Publikasi, Submit

\begin{abstract}
Submitting articles to the Online Journal System (OJS) has been seen as a difficult thing for the public. The proposed community service program is a community service program that aims to provide easy solutions for the community to publish research results. The public can take advantage of technology to publish works through the Open Journal System (OJS). Based on the background of the proposer team and the experience of the proposer team, hereby, the team proposes a community service program with the theme "Tutorial Submit Articles on the Online Journal System (OJS)". The training will provide material and practical presentation. The results of these activities are expected to provide benefits for academics and other researchers to publish their work.
\end{abstract}

Keywords : Article, Publication, Submit

\section{Introduction}

Science develops continuously every time. The development of science and technology cannot be separated from current technological advances. Various efforts to advance the quality of science continue to be made. The twentieth century recorded important leaps in the development of science and technology. Discoveries and creations take place alternately, while scientific information is produced rapidly every five years, even in certain disciplines such as genetics every two years, making it difficult to disseminate, store, trace and absorb it. All of that in turn requires technology.

Science basically must be used and utilized for the benefit of mankind. Science can be used as a means or tool in improving the standard of human life by taking into account human nature, human dignity, and the preservation or balance of nature. Scientific knowledge for the benefit of humans is obtained, compiled and used communally and universally. Communal means that science is knowledge that belongs 
together, everyone has the right to use knowledge according to their needs. Universal means that science has no connotations of race, ideology, or religion (Surajiyo, 2008).

Every academician who has formal education and researchers always carries out scientific updates by conducting research, both in the exact and social fields. The research they do is solely to prepare human civilization for a better future. The results of research in the field of extracts that contribute to better civilization, for example the invention of $4 \mathrm{G}$, while the results of social research that contribute to civilization, for example in the case of companies predicting bankruptcy.

Research results produced by researchers will not have an impact on society if researchers only store them in the laboratory. In order to have an impact on society, the research must be published by researchers. One of the publications that can be done by researchers is publication in journals. By being published in a journal, the public or the public gain new knowledge. Even in the last ten years, journal reference sources have taken precedence over books. This is because science in journals is more advanced, journals can be published several times a year and contain new knowledge, while books may only be published once a year.

Public enthusiasm for reading journals also motivates researchers to conduct research for publication. However, some journal writers have difficulty submitting research articles to journals, because currently journals are managed using an online system, one of which is the Open Journal System (OJS). Almost all journals in Indonesia use OJS in the journal publishing process, even the national accreditation process is now also based on OJS. OJS is no longer a side knowledge for researchers, but researchers also have to understand how to submit scientific articles through OJS. Some article writers have problems submitting articles through OJS, this causes articles cannot be processed in OJS so they cannot be published. Therefore,

\section{Implementation Method}

The Tutorial Submit Articles in the Open Journal System (OJS) is carried out online. The activity is carried out for 1 day starting at 09.00 to 12.00 WIB on the 14 th of June 2021.

Tutorial Training on Submit Articles on the Open Journal System (OJS) for academics, students and the public. Participants targeted to participate are 20 participants. The next stage is to prepare Meeting ID: 94566851343 and Passcode: 667607. The infrastructure facilities that are prepared include computers and internet connections. Then the stage of preparing the material made in the form of powerpoint is carried out.

The method of activities carried out is in the form of lectures and discussions. The community service team will provide material about the Open Journal System (OJS). This training will be presented by speakers who come from team members. Next, the community service team will practice submitting articles to the Open Journal System (OJS). This training was presented by a speaker who came from one of the community service teams.

\section{Results and Discussion}

The preparations made include a computer, and a Wifi Internet connection that will be used by the presenters to deliver the material online. This Tutorial Submit Article activity in the Open Journal System (OJS) is one of a series of Community Service activities organized by the D3 Accounting Study Program lecturer independently. The entire series of activities is carried out for 1 day starting at 09.00 to 12.00 WIB on the 
14th of June 2021. The activity begins with the participant registration process at 08.30 WIB. Participants enter the virtual room 30 minutes before the activity. After all participants and presenters entered, it was followed by an opening by the Head of the D3 Accounting Study Program.

At the opening of the activity, several things were conveyed, namely the purpose of implementing the activity, as well as the benefits of the training activities carried out. The activity continued with Tutorial Material Submit Articles on the Open Journal System (OJS) which was delivered by Dabella Yunia and moderated by Chandra Prasadhita. The training materials provided include Introduction to the Online Journal System (OJS), Submit Stages on OJS and OJS Menus which often get the attention of writers and readers. From all the material presented, enthusiasm was very high, it was seen during the question and answer session. Participants said that so far they do not know how to submit articles to OJS, so their research has not been published so far.

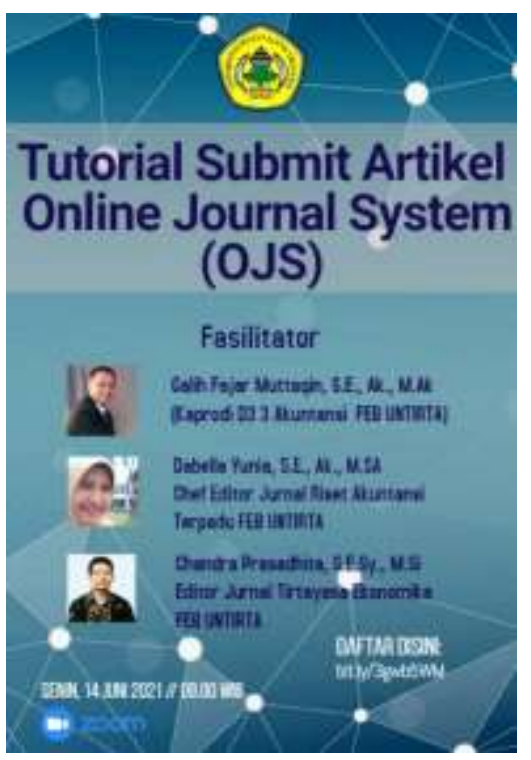

Figure 1. Tutorial Activity Flyer Submit Articles on the Online Journal System (OJS)

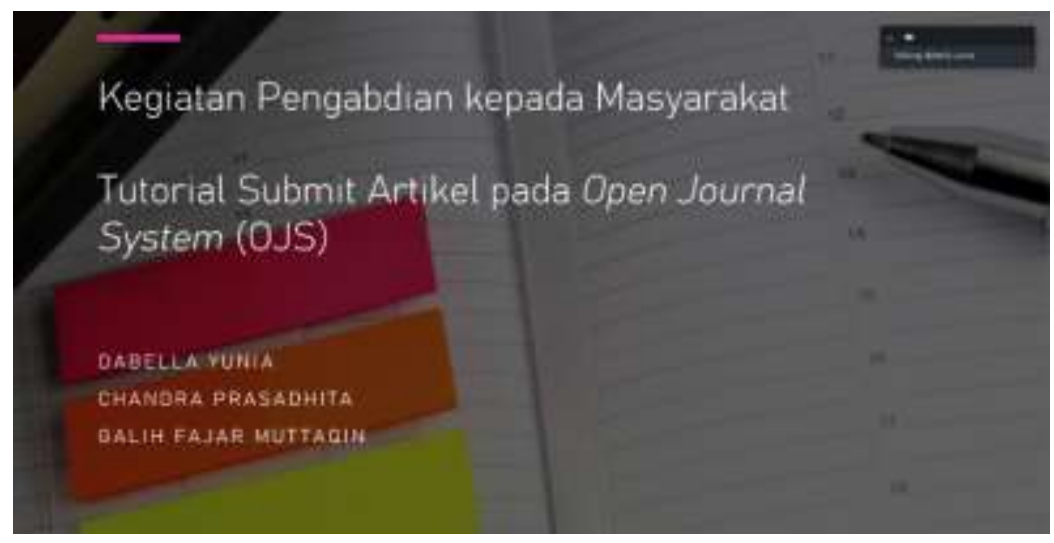

Figure 2. Submission of Material 


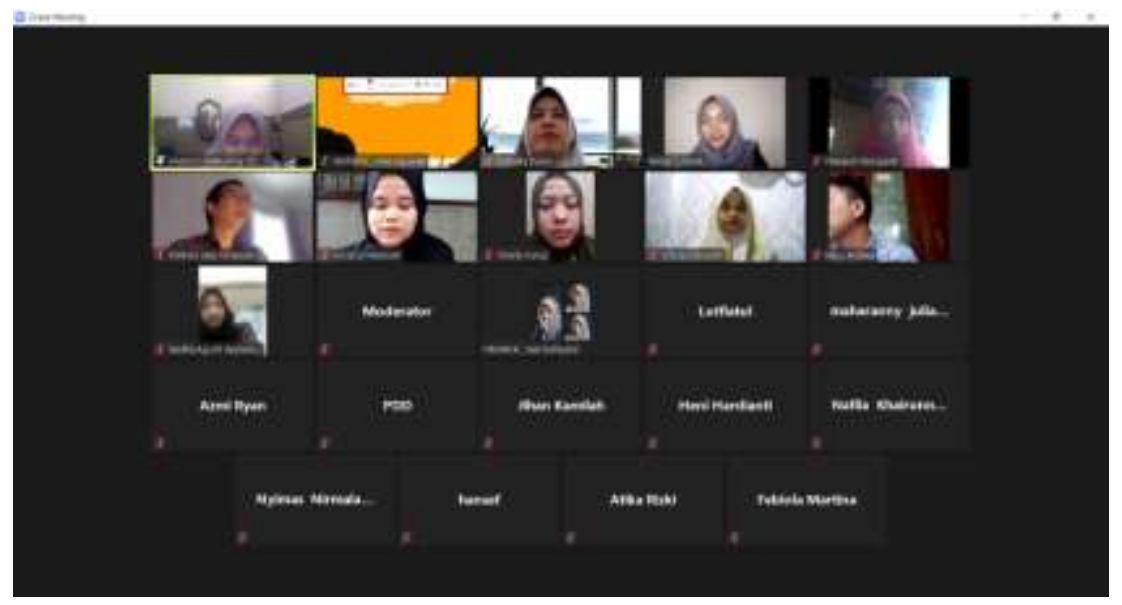

Figure 3. Participants

\section{Conclusion}

From the whole series of activities in this training program, several conclusions can be drawn that submitting articles to the Online Journal System (OJS) is not yet used by all parties. Based on the evaluation results, it is known that the participants of the Tutorial Submit Articles on the Open Journal System (OJS) have high enthusiasm to submit their own articles to OJS. By being able to submit articles independently, it can encourage the academic environment to publish works in scientific journals.

Socialization of submitting articles to the Online Journal System (OJS) must be carried out both on campus (Sultan Ageng Tirtayasa University) and outside campus. The ability to submit articles on OJS supports academics in publishing papers.

\section{Acknowledgment}

Thank you to those who have supported this activity, namely the participants of the webinar, Faculty of Economics and Business, Sultan Ageng Tirtayasa University, Institute for Research and Community Service, University of Sultan Ageng Tirtayasa.

\section{Reference}

Surajiyo. 2008. Filsafat IImu \& Perkembangannya di Indonesia. Bumi Aksara, Jakarta. 